\title{
Calculating flux to predict future cave radon concentrations
}

Matt D. Rowberry¹, Xavi Martí2 ${ }^{2}$ Carlos Frontera ${ }^{3}$, Marco J. Van De Wiel ${ }^{4}$, Miloš Briestenský1

${ }^{1}$ Institute of Rock Structure \& Mechanics, Czech Academy of Sciences, V Holešovičkách 41, 18209 Prague 8, Czech Republic; ${ }^{2}$ Institute of Physics, Czech Academy of Sciences, Cukrovarnická 10, 16253 Prague 6, Czech Republic; ${ }^{3}$ Institut de Ciència de Materials de Barcelona, ICMAB-CSIC, Campus UAB, E-08193 Bellaterra, Barcelona, Spain; ${ }^{4}$ Centre for Agroecology, Water, and Resilience (CAWR), Coventry University, Priory Street, Coventry, CV1 5FB, United Kingdom.

* corresponding author: rowberry@irsm.cas.cz

Abstract: Cave radon concentration measurements reflect the outcome of a perpetual competition which pitches flux against ventilation and radioactive decay. The mass balance equations used to model changes in radon concentration through time routinely treat flux as a constant. This mathematical simplification is acceptable as a first order approximation despite the fact that it sidesteps an intrinsic geological problem: the majority of radon entering a cavity is exhaled as a result of advection along crustal discontinuities whose motions are inhomogeneous in both time and space. In this paper the dynamic nature of flux is investigated and the results are used to predict cave radon concentration for successive iterations. The first part of our numerical modelling procedure focuses on calculating cave air flow velocity while the second part isolates flux in a mass balance equation to simulate real time dependence among the variables. It is then possible to use this information to deliver an expression for computing cave radon concentration for successive iterations. The dynamic variables in the numerical model are represented by the outer temperature, the inner temperature, and the radon concentration while the static variables are represented by the radioactive decay constant and a range of parameters related to geometry of the cavity. Input data were recorded at Driny Cave in the Little Carpathians Mountains of western Slovakia. Here the cave passages have developed along splays of the NE-SW striking Smolenice Fault and a series of transverse faults striking NW-SE. Independent experimental 
observations of fault slip are provided by three permanently installed mechanical extensometers. Our numerical modelling has revealed four important flux anomalies between January 2010 and August 2011. Each of these flux anomalies was preceded by conspicuous fault slip anomalies. The mathematical procedure outlined in this paper will help to improve our understanding of radon migration along crustal discontinuities and its subsequent exhalation into the atmosphere. Furthermore, as it is possible to supply the model with continuous data, future research will focus on establishing a series of underground monitoring sites with the aim of generating the first real time global radon flux maps.

Keywords cave radon concentration; cave radon flux; cave ventilation; radioactive decay; fault slip; numerical modelling. 


\section{Highlights}

- Cave radon concentrations pitch flux against ventilation and radioactive decay

- Exhalation is dominated by radon advection along discontinuities such as faults

- Our numerical model isolates flux and then predicts future radon concentrations

- Independent observations confirm the close relationship between flux and fault slip 


\section{INTRODUCTION}

Radon $\left({ }^{222} \mathrm{Rn}\right)$ is a radioactive noble gas that results from the decay of solid radium $\left({ }^{226} \mathrm{Ra}\right)$. The release of radon is controlled by the alpha particle recoil mechanisms that expel radon from radium. Whether a newly formed radon atom remains in the mineral grain or whether it enters the intergranular pore space is determined by the position of the radium atoms and the direction of radon atom recoil (Appleton 2013). The vast majority of radon atoms remain within the mineral grain only to decay once again into a solid product while the tiny minority that enter the intergranular pore space then begin the process of migration towards the surface. Migration is controlled largely by the water retention and fluid transmission characteristics of the bedrock (Åkerblom \& Mellander 1997). The latter include its permeability, its porosity, and its pore size distribution as well as the nature of any crustal discontinuities such as faults, fractures, and joints (Appleton 2013). It is far more common for radon to be emitted into a liquid phase rather than into a gas phase. Radon migration in the liquid phase occurs with the help of carrier fluids and the radon will remain in the liquid phase until a gas phase is introduced. Clearly radon migration in the liquid phase is going to be influenced by factors such as groundwater circulation whereas migration in the gas phase is going to be influenced by factors such as the diffusion characteristics of the gas.

Radon is generally abundant in confined underground spaces such as caves, tunnels, and mines (Stannard 1988). The numerical model presented in this paper is based on input data recorded in a cave. Measurements of cave radon concentration reflect the outcome of a perpetual competition which pitches flux against ventilation and radioactive decay (Wilkening \& Watkins 1976). In the absence of ventilation it is possible for the radon concentration in such settings to approach that characteristic of soil gas (Wilkening 1990). Cave radon clearly accumulates as a result of exhalation from the confining rock mass but it is important to have a basic understanding of the contributions made by diffusive transport and advective transport. The distances over which radon atoms can be transported by diffusion are limited by the short half life of radon $\left(t_{1 / 2}=3.82 \mathrm{~d}\right)$ while the distances over which they can be transported by advection along structural discontinuities is significantly further, perhaps more than one hundred metres (Appleton 2013). Exhalation by diffusion from solid limestone containing $2.2 \mathrm{mg} \mathrm{kg}^{-1} \mathrm{U}$ may be expected to result in cave radon concentration 
measurements in the order of $100 \mathrm{~Bq} / \mathrm{m}^{3}$ (Appleton 2013). The fact that radon concentration measurements in such settings are generally greater by at least one order of magnitude emphasises the importance of exhalation by advection along structural discontinuities. This importance may be heightened in caves compared to other underground settings as their passages often develop along precisely the same faults and fractures as those used for radon migration.

Faults and fractures permit the efficient transmission of radon to the surface due to the fact that fluids readily migrate along such crustal discontinuities. Consequently many studies have used high radon concentration measurements to infer the presence of discontinuities under soil or glacial drift. High radon concentration is more likely to be encountered if the discontinuities are active (Swakoń et al. 2005; Ielsch et al. 2010; Neri et al. 2011). Discontinuities in the near surface environment may be thought of as active if they are subjected to thermal expansion as this leads to dilation and constriction whereas those at greater depths tend to be more susceptible to slip caused by either gravitational or tectonic processes. The EU-TecNet fault displacement monitoring network has been making direct experimental observations of fault slip at more than one hundred sites across central Europe. More than a decade of data demonstrate that fault motion in this intracratonic region is commonly characterised by steady progressive creep trends: these may be horizontal (strike-slip), vertical (dip-slip), or a combination of the two (oblique-slip). However, the steady progressive creep trends are sometimes interrupted by short periods of anomalous activity, interpreted to reflect a short term perturbation in the regional stress field (Stemberk et al. 2010; Košt'ák et al. 2011; Briestenský et al. 2015). During these periods the progressive creep trends may be subjected to, for example, a conspicuous reversal; a sudden enduring displacement; or a series of oscillatory displacements. It follows that significant displacements should also be evidenced by radon anomalies especially given that numerous studies have related radon concentration anomalies with other geodynamic phenomena such as earthquakes (Igarashi et al. 1995; Briestenský et al. 2014; Hwa Oh \& Kim 2015).

Once radon has been exhaled into a confined underground space it is then subject to the processes responsible for liberating it into the atmosphere. The most comprehensive recent account of underground meteorology is that of Badino (2010). Air exchange is 
strongly influenced by convective circulation caused as a result of internal-external buoyancy pressure differences and barometric circulation caused as a result of internalexternal pressures differences. The former is particularly important for caves with more than one entrance at different heights whereas the latter is more important for caves with only one entrance or for caves with only extremely small entrances. Diurnal and seasonal circulation changes often result in diurnal and seasonal fluctuations in natural gas and aerosol concentrations (Bezek et al. 2012). The effects of such changes on radon concentration are particularly well known because radon is commonly used as a tracer for cave ventilation modelling (Cunningham \& Larock 1991; Hakl et al. 1997; Tanahara et al. 1997; Przylibski 1999; Perrier et al. 2004; Kowalczk \& Froelich 2010; Gregorič et al. 2014). However, although the processes governing air exchange are well understood, the mass balance equations used to model changes in radon concentration through time routinely treat flux as a constant. This mathematical simplification sidesteps an intrinsic geological problem: the majority of radon exhalation occurs as a result of advection from crustal discontinuities whose motions are clearly inhomogeneous in both space and time. In this paper the dynamic nature of flux is investigated and the results are used to predict cave radon concentration for successive iterations.

\section{STUDY AREA}

The input data used for our numerical model were recorded at Driny Cave in the geodynamically active Little Carpathian Mountains of western Slovakia (Figure 1). This mountain range trends SW-NE along the southeastern margin of the Bohemian Massif and forms part of the Alpine-Carpathian Orogenic Belt (Lenhardt et al. 2007). It comprises a mesh of clearly defined morphostructural units (Marko et al. 1991) bordered to the northwest by the Vienna Basin and to the southeast by the Pannonian Basin (Plašienka et al. 1997). The range is characterised by moderate seismicity: the strongest earthquake, with a magnitude of $\mathrm{M}_{\mathrm{s}}=5.7$, occurred in the epicentral area of Dobrá Voda on 9 January 1906 and was followed by a large aftershock, with a magnitude of $\mathrm{M}_{\mathrm{S}}=5.3$, on 16 January 1906 (Zsíros 2005). Other events with magnitudes of greater than $\mathrm{M}_{\mathrm{L}}=4.0$ occurred in 1904, 1930, and 1967 (Fojtíková et al. 2010). Notable recent earthquakes were recorded close to the town of Vrbové, with a magnitude of $\mathrm{M}_{\mathrm{L}}=3.3$, on 13 March 2006, and close to the town of Studienka, with a magnitude of $\mathrm{M}_{\mathrm{L}}=3.4$, on 5 March 2012. The stress field appears to be dominated by 
NE-SW horizontal extension (Kováč et al. 2002) although NE-SW horizontal compression has been identified around the epicentral area of Dobrá Voda (Fojtíková et al. 2010).

Driny Cave is located at the contact between the Little Carpathian Mountains and the adjacent Pannonian Basin. The area around the cave hosts a range of slope deformations while the limestone cliffs which host the entrance to the cave are characterised by numerous open fissures (Briestenský et al. 2011a). The cave itself has developed in the lower Cretaceous locally schistose marly limestones of the Hlboč Formation (Michalík et al. 1992) as a result of corrosion by meteoric waters seeping along splays of the NE-SW striking Smolenice Fault and a series of transverse faults striking NW-SE (Droppa 1951). Its main entrance is situated at $399 \mathrm{~m}$ asl, its smaller upper entrance is situated at $431 \mathrm{~m}$ asl, its chimney descends a total of $36 \mathrm{~m}$, and its passages attain a total length of $680 \mathrm{~m}$ (Bella 2006). Faults within the cave often exhibit striations and slickencrysts. These features indicate that the splays of the NE-SW striking Smolenice Fault are primarily affected by dip slip displacements while the transverse faults striking NW-SE are primarily affected by strike slip displacements (Briestenský et al. 2011a). Its walls are commonly covered by flowstones while the ceilings and floors host numerous types of dripstone. The presence of tiny, fresh, cracks in dripstones developing close to fault outcrops suggests that these crustal discontinuities are still active (Briestenský et al. 2011a,b).

Three mechanical extensometers have been installed to measure fault slip in the cave. The monitoring points Driny 1 and Driny 2 are installed across parallel splays of the Smolenice Fault whereas Driny 3 is installed across one of the transverse faults (Briestenský et al. 2011a,b). Results from Driny 1 and Driny 2 present evidence of sinistral strike slip and uplift of the northwestern block whereas results from Driny 3 present evidence of dextral strike slip and uplift of the northeastern block (Table 1). In detail, however, the data are more complicated. At Driny 1, large reversals in the sense of dip slip displacement were recorded towards the end of 2009 and at the beginning of 2010 while dextral strike slip dominated between 2010 and 2012. At Driny 2, large reversals in the sense of dip slip displacement were again recorded towards the end of 2009 and at the beginning of 2010 while dextral strike slip dominated slightly later, 
between 2012 and 2013. At Driny 3, subsidence of the northeastern block was recorded between 2011 and 2013 while sinistral strike slip dominated between 2010 and 2012 . The anomalous fault slip trends recorded between 2010 and 2013 are interpreted to reflect a short term perturbation in the regional stress field (see, for example, Stemberk et al. 2010; Košt'ák et al. 2011; Briestenský et al. 2015).

\section{EXPERIMENTAL METHODS}

Measurements of equilibrium equivalent radon concentration, ambient temperature, and barometric pressure were obtained every thirty minutes from January 2010 to August 2011 while measurements of fault slip have been recorded at Driny Cave once every two weeks since January 2006. The measurements of equilibrium equivalent radon concentration were obtained by a radon progeny monitor TS96 ${ }^{1}$. This was installed in a distal part of the cave in which the host limestone is characterised by low calculated mass activity (Štelcl et al. 2002). These instruments use a $200 \mathrm{~mm}^{2}$ semiconductor barrier detector to measure the alpha activity of ${ }^{218} \mathrm{Po}$ and ${ }^{214} \mathrm{Po}$ with an accuracy of $+/-10 \%$, a resolution of $2 \mathrm{~Bq} / \mathrm{m}^{3}$, and a measuring range between $0 \mathrm{~Bq} / \mathrm{m}^{3}$ and $1999 \mathrm{~Bq} / \mathrm{m}^{3}$. $\mathrm{EEC}_{\mathrm{Rn}}$ measurements were converted to radon concentration using a constant radioactive equilibrium coefficient of $\mathrm{F}=0.5$. It should be noted that the validity of applying a constant coefficient is discussed in Section 6.3. The measurements of ambient temperature were obtained using two Comet System instruments R0110. One was installed outside in a cleft above the lower entrance to the cave and one was installed at the distal end of the cave, approximately five metres from the radon progeny monitor. These instruments have an accuracy of $\pm 0.4^{\circ} \mathrm{C}$, a resolution of $0.1^{\circ} \mathrm{C}$, and a measuring range between $-40^{\circ} \mathrm{C}$ and $+80^{\circ} \mathrm{C}$. The measurements of barometric pressure were recorded by an Eijkelkamp BaroDiver. This was installed in a hydrogeological borehole in the nearby epicentral area of Dobrá Voda. These instruments have a resolution of $\pm 0.1 \mathrm{~cm} \mathrm{H}_{2} \mathrm{O}$, a typical accuracy of $\pm 0.5 \mathrm{~cm} \mathrm{H}_{2} \mathrm{O}$, and can withstand a maximum pressure of $15 \mathrm{~m} \mathrm{H}_{2} \mathrm{O}$. The readings are converted to give atmospheric pressure in $\mathrm{hPa}$. The measurements of fault slip are recorded using three mechanical extensometers TM-71 (Košt'ák 1991). Two are installed across splays of the Smolenice Fault (dip $\rightarrow$ dip direction: $70^{\circ} \rightarrow 290^{\circ}$ and $70^{\circ} \rightarrow 110^{\circ}$ ) while the third is installed across

\footnotetext{
${ }^{1}$ The TS96 was developed at the Institute of Particle \& Nuclear Physics at Charles University in Prague and approved for equilibrium equivalent radon concentration monitoring by the Czech Metrology Institute.
} 
one of the transverse faults $\left(75^{\circ} \rightarrow 040^{\circ}\right)$. These instruments use the moiré phenomenon of optical interference to record displacements in a three dimensional Cartesian coordinate system with a resolution of $\pm 0.007 \mathrm{~mm}$ (Martí et al. 2013).

\section{NUMERICAL METHODS}

\subsection{Ventilation mechanisms, temperature gradients, and air flow velocities}

The presented numerical model assumes a system whose geometry is based on that of Driny Cave (Figure 2A). The first step in the first stage of the modelling procedure specifies the ventilation mechanism. In our model, as at Driny Cave, the air flow direction reflects the presence of two entrances at discordant heights. The specific mechanism is governed by Bernoulli's Principle. When the inner temperature is greater than the outer temperature, the comparatively warm, less dense, air inside the cave is forced out of the upper entrance as a result of the chimney effect. When the outer temperature is greater than the inner temperature, the comparatively cold, denser, air inside the cave is forced out of the lower entrance as a result of Torricelli's Law.

The second step defines an intermediate parameter, $T^{*}$, to account for the difference between the temperature inside the cave, $T_{i}$, and the temperature outside the cave, $T_{o}$, as illustrated in Eq. 1:

$$
T^{*}=\sqrt{\frac{|\Delta \mathrm{T}|}{T_{j}}}
$$

Where: $\Delta \mathrm{T}$ is the observed difference between the outer temperature and the inner temperature $\left(\Delta \mathrm{T}=T_{o}-T_{i}\right)$ and $T_{j}$ is the temperature corresponding to each ventilation mechanism ( $T_{j}=T_{i}$ for chimney effect and $T_{j}=T_{o}$ for Torricelli's Law). This parameter is needed at various points in the numerical modelling procedure and it allows us to present more concise mathematical formulas in subsequent steps.

The third step calculates air flow velocity through the system on the basis of Bernoulli's Principle, irrespective of the specific ventilation mechanism, as illustrated in Eq. 2: 


$$
v=T^{*} \sqrt{2 g H}
$$

Where: $g$ is gravity acceleration and $H$ is the height difference between the uppermost and lowermost points of the cave. The modelled flow velocities for air passing through the upper entrance, if $T_{i}>T_{o}$, or the lower entrance, if $T_{o}>T_{i}$, are presented in Figure 2B while an extracted air flow velocity profile is presented in Figure 2C. These demonstrate, first, that air flow ceases when there is no temperature gradient and, second, that the air flow velocity is not a linear function of the temperature gradient.

\subsection{Modelling radon flux and predicting radon concentration}

The first step in the second stage considers the seminal mass balance differential equation of Wilkening \& Watkins (1976), routinely used to model cave radon concentration changes, as illustrated in Eq. 3:

$$
\frac{\mathrm{dc}}{\mathrm{dt}}=\phi-\lambda \cdot c-\frac{Q}{V} \Delta c-\frac{D}{L} \Delta c
$$

Where: $\phi$ is radon flux; $c$ is radon concentration; $\lambda$ is the radioactive decay constant; $Q$ is the displaced volume of air; $V$ is the total volume of air in the cave; $D$ is the radon diffusion coefficient between two points separated a length $L$ in the absence of ventilation; $\Delta \mathrm{c}$ is the difference between radon concentration measured inside and outside the cave. This term can be simplified by assuming that the radon concentration outside the cave is zero (i.e. $\Delta \mathrm{c}=\mathrm{c}$ ) and by neglecting the diffusion term because, in the absence of ventilation, radon is only transported for short distances compared to the dimensions of a typical cave.

The second step consolidates the variables related to cave geometry into one symbol, allowing us to present more concise mathematical formulas in subsequent steps, as illustrated in Eq. 4:

$$
\gamma \equiv \frac{k_{j}}{l_{j}} \sqrt{2 g H} .
$$


Where: $k_{j}$ is a coefficient from 0 to 1 that accounts for the proportion of the ceiling or entrance which acts as an aperture for air flow and $l_{j}$ is a length scale equal to the height of the cave or the magnitude of the length of the cave. The proportion of the ceiling and the height of the cave are used when ventilation is dominated by the chimney effect whereas the proportion of the entrance and the magnitude of the length of the cave are used when ventilation is dominated by Torricelli's Law. The influence that this variable exerts on the outputs of the numerical model is discussed in Section 6.1.

The third step isolates flux in the mass balance equation in order to simulate real time dependence among the variables, as illustrated in Equation 5:

$$
\phi(t)=\lambda \cdot c+\gamma T^{*} \cdot c+\frac{\mathrm{dc}}{\mathrm{dt}}
$$

This equation connects the perpetual competition pitching flux, the ultimate source of the radon inside the cave, against ventilation. It demonstrates that the retrospective analysis of flux requires only routinely available data: radon concentration, inner temperature, and outer temperature.

The fourth step delivers an expression to compute radon concentration for successive time instants. It is possible to predict radon concentration, $c$, for successive time instants, $t$, using the preceding radon concentration, $c_{0}$, and the ambient temperatures, as illustrated in Equation 6:

$$
c \approx c_{0}+t \cdot\left(\phi-c_{0}\left(\lambda+\gamma T^{*}\right)\right)
$$

As in the mass balance differential equation of Wilkening \& Watkins (1976), flux is thought of as favourable, the term preceded by a plus sign, while ventilation and radioactive decay are thought of as unfavourable, the terms preceded by a minus sign. The relevance of this equation is illustrated by a simulation presented in the following section while a flow diagram summarising the outlined numerical modelling procedure is presented in Figure 3. 


\section{MODEL IMPLEMENTATION}

An illustrative numerical simulation is presented in Figure 4 to demonstrate the relevance of Equation 6. Figure 4A outlines a hypothetical ventilation scenario, Figure 4B outlines a hypothetical flux scenario, and Figure 4C presents iterative estimations of future radon concentration. The first half of the numerical simulation is characterised by an increase and decrease in the air flow velocity while the second half is characterised by a complete absence of ventilation. Flux remains constant throughout this period except at those times when it is interrupted by a spontaneous anomaly. During the first half of the simulation the radon concentration decreases rapidly as ventilation successfully counteracts flux. Furthermore, the first pair of flux anomalies clearly influence the radon concentration. During the second half of the simulation the radon concentration increases steadily as ventilation is no longer able to counteract flux. However, the second pair of flux anomalies do not clearly influence the radon concentration. This simulation suggests that radon concentration is not necessarily a reliable indicator of radon flux.

Figure $5 \mathrm{~A}-\mathrm{C}$ presents time series of inner temperature, $T_{i}$, outer temperature, $T_{o}$, and radon concentration, $c$, recorded at Driny Cave from January 2010 to August 2011. It is, unfortunately, not possible for us to extend this term as it represents the only period in which the input data were recorded simultaneously. Figure 5D maps the relationship between measured radon concentration, $c$, and the outer temperature, $T_{o}$, by plotting the number of events that represent a single pair of the variables. The vertical line to the left denotes the freezing point of water while the vertical line to the right denotes no temperature gradient. This panel reveals a complex, nonlinear, seasonal dependency as higher radon concentration pairs with both lower outer temperatures during the winter, when cave ventilation is dominated by the chimney effect, and higher outer temperatures during the summer, when ventilation follows Torricelli's Law. The assumption that ventilation ceases in the absence of a temperature gradient and, consequently, increases radon concentration is not observed in our model. Far from being a maximum, at $T_{o} \approx T_{i}$, the number of events that represent a single pair of the variables appears to be close to a minimum. 
Given that cave radon concentration measurements reflect the outcome of a perpetual competition which pitches flux against ventilation and radioactive decay then the aforementioned contradiction adds further weight to the idea that flux is not a constant. Figure 5E maps the relationship between measured radon concentration, $c$, and the intermediate parameter, $T^{*}$, by plotting the number of events that represent a single pair of the variables. The intermediate parameter, $T^{*}$, captures the majority of the experimental data, depicted by warmer colours, in a manner that cannot be attained by linear combinations. This panel, first, demonstrates the close relationship between radon concentration and the temperature gradient and, second, suggests that greater radon concentration measurements pair with faster ventilation rates. The second point is worthy of elaboration. Irrespective of whether radon migrates by diffusion or advection, its ultimate source has to be the confining rock mass, so the suggestion that greater radon concentration measurements pair with faster ventilation rates implies that ventilation is able to act as a pump which draws radon into the cave. It confirms the nonlinear dependence between flux and the temperature gradient.

Figure 6 interrogates flux modelled as a function of the input data obtained at Driny Cave. Figure 6A maps the relationship between the measurements of radon concentration, $c$, and the modelled flux, $\varphi$, by plotting the number of events that represent a single pair of the variables. This panel demonstrates, first, the close relationship which exists between the measurements of radon concentration and the modelled flux and, second, that the modelled flux is characterised by a generally narrow set of values. The second point is once again worthy of elaboration. There appears to be a reasonable correspondence between the flux values we have obtained though our modelling and those used as constants during cave ventilation modelling (see, for example, Gregorič et al. 2011). It emphasises that this mathematical simplification is acceptable as a first approximation. Figure 6B plots modelled flux as a function of time. This panel shows a series of flux anomalies rising above a seemingly oscillatory background. The four most significant anomalies occurred in January 2010, October 2010, November 2010, and March 2011. In the following section the timing of these anomalies is discussed in relation to independent experimental observations of fault slip. 
Figure 7 compares measurements of radon concentration and radon concentration predictions for three different time horizons made using Equation 6. The input data are presented in Figure 5 and the flux is obtained using Equation 5. Figure 7A-C presents data pertaining to a thirty minute time horizon, Figure 7D-F presents data pertaining to an eight hour time horizon, and Figure 7G-I presents data pertaining to a twenty four time horizon. For each time horizon the measurements of radon concentration and radon concentration predictions are compared as a function of time; the relationship between the measurements of radon concentration and radon concentration predictions are mapped; and the difference between the measurements of radon concentration and radon concentration predictions are plotted - positive residuum indicates overestimation of the radon concentration while negative residuum indicates its underestimation. It is clear that there are close relationships between the measurements of radon concentration and radon concentration predictions. With a thirty minute time horizon our radon concentration predictions never deviate from the measured values by more than $100 \mathrm{~Bq} / \mathrm{m}^{3}$ while with a twenty four hour time horizon our radon concentration predictions rarely deviate from the measured values by more than $1000 \mathrm{~Bq} / \mathrm{m}^{3}$. It is also clear that overestimating the predicted radon concentration is more common than underestimating it.

\section{DISCUSSION}

\subsection{The variable $\gamma$}

The variable $\gamma$ was introduced in the second stage of the numerical model to consolidate all the parameters related to cave geometry. It accounts for the proportion of the ceiling or entrance which acts as an aperture for air flow and incorporates a length scale equal to the height of the cave or the magnitude of the length of the cave. Three plots of flux modelled as a function of the input data from Driny Cave are presented in order to interrogate the extent to which our model is sensitive to the parametric inputs used to define the variable $\gamma$ (Figure 8). In all three cases the height is fixed to forty metres, as at Driny Cave, and the length is fixed to one hundred metres. These parameters have been fixed because they are generally easier to estimate than the proportion of the ceiling or entrance which acts as an aperture for air flow. The first case estimates that the proportion of the ceiling or entrance which acts an aperture for air flow equates to $0.1 \%$ (Figure $8 \mathrm{~A}$ ). The second case estimates that the proportion of the ceiling or 
entrance which acts an aperture for air flow equates to $1 \%$ (Figure 8B). The third case estimates that the proportion of the ceiling or entrance which acts an aperture for air flow equates to $10 \%$ (Figure 8C). It should be noted that the values used for our numerical model are very similar to those presented in the second case (cf. Figure 6B \& Figure 8B).

Figure 8 demonstrates, first, that the flux anomalies occur at precisely the same times irrespective of the proportion of the ceiling or entrance assigned to act as an aperture for air flow and, second, that the magnitude of the flux anomalies remains comparable irrespective of the proportion of the ceiling or entrance assigned to acts as an aperture for air flow. The most conspicuous changes relate to the magnitude of the flux in the oscillatory background but such changes are not relevant in the context of the present study. Inspection of the parameters consolidated by $\gamma$ reveals that its range must fall between $\gamma=0$, if air flow is completely impeded, and $\gamma \approx 1$, if the entirety of the entrance or ceiling is completely open (this scenario is clearly a physical impossibility). Typical cave geometries will result in $\gamma$ being ascribed a value ranging from approximately 0.01 to approximately 0.0001 . If the ascribed value is smaller than the actual value then this would underestimate the role played by ventilation whereas if the ascribed value is greater than the actual value then this would underestimate the roles played by flux and radioactive decay. The comparison presented here demonstrates that the use of approximations will not fundamentally change the results of the numerical modelling, as long as completely unrealistic values are not ascribed. The variable $\gamma$, which itself has no physical meaning, simply acts as a scaling coefficient.

\subsection{Flux anomalies and fault slip}

The validation of our numerical model is hindered because flux cannot be measured directly and measurements of radon concentration are needed as inputs in the model. To overcome this problem we compare our flux anomalies to independent experimental observations of fault slip recorded by three mechanical extensometers in Driny Cave. This site is one of more than one hundred which comprise the European fault displacement monitoring network EU-TecNet. The extensometers measure displacement in a three dimensional Cartesian coordinate system: the $x$-coordinate represents dilation across the fault; the $y$-coordinate represents strike slip 
displacements; and the $z$-coordinate represents dip slip displacement. Typically the strike slip and dip slip displacements at any given monitoring point are characterised by progressive creep trends. These are sometimes interrupted by shorter periods of anomalous activity during which one or both of the slip components may be affected by, for example, conspicuous reversals in the progressive creep trend; a sudden enduring displacement; or a series of oscillatory displacements (see, for example, Briestenský et al. 2015). It is important to note that parallel faults tend to move simultaneously but their sense of movement may differ while perpendicular faults may or may not interact with one another.

The four most significant flux anomalies occurred in January 2010, October 2010, November 2010, and March 2011. Figure 9A presents the strike slip and dip slip displacements from Driny 1; Figure 9B presents the strike slip and dip slip displacements from Driny 2; Figure 9C presents the strike slip and dip slip displacements from Driny 3. The anomaly in January 2010 is reflected by a significant dip slip displacement at Driny 1 and a significant strike slip displacement at Driny 2. The anomalies in October 2010 and November 2010 are reflected by a series of dip slip displacements, incorporating reversals in the sense of movement, at Driny 3. The anomaly in March 2011 is reflected by a significant dip slip displacements at Driny 3. In all instances the anomalous fault displacements preceded the modelled flux anomaly. It has been proposed that fault slip at Driny Cave reflects both slope deformation and tectonic deformation (Briestenský et al. 2011a). Irrespective of the specific geodynamic process, it is clear that fault slip plays an important role in facilitating radon migration along discontinuities in the crust. The novelty of our experimental design should not be overlooked. It is only possible for us to compare our flux anomalies to experimental observations of fault slip because, first, we monitor faults with different orientations and, second, we are able to record displacements in a three dimensional Cartesian coordinate system.

\subsection{Using the numerical model}

To summarise, the presented numerical model is straightforward to use, as illustrated by Figure 3. The dynamic variables are represented by the outer temperature, the inner temperature, and the radon concentration while the static variables are represented by 
the radioactive decay constant and a range of parameters related to geometry of the cavity. In Section 3 it was stated that the $\mathrm{EEC}_{\mathrm{Rn}}$ measurements recorded by the radon progeny monitor had been converted into radon concentration by applying a constant radioactive equilibrium coefficient of $\mathrm{F}=0.5$. It is accepted that the use of a constant equilibrium coefficient does introduce uncertainties into the reported radon concentration. This approach, however, is justified on the following grounds. The focal point of the presented study is the mass balance equation and, in particular, the dynamic nature of the flux term. In this context, the precise calculation of radon concentration is less important than being able to identify the general patterns. If we were to apply a dynamic radioactive equilibrium coefficient then each of the equilibrium equivalent concentration measurements is effectively subjected to a different scaling coefficient. This may serve to modulate the amplitude of a flux anomaly but it cannot change the timing of an anomaly nor can it create or eradicate flux anomalies. In this regard it is important to recall that the four most significant flux anomalies rise above baseline values by a factor of approximately 4 . Furthermore, the close relationship between our modelled flux anomalies and independent observations of fault slip also indicates that our use of a constant radioactive equilibrium coefficient is appropriate.

The presented numerical modelling procedure incorporates a small number of assumptions. First, that air flow velocity is driven solely by the temperature gradient, second, that radon diffusion is negligible and, third, that flux is spatially uniform. It would be possible to develop and tune more sophisticated versions of the numerical model so that it is better able to account for site specific conditions including those encountered in other underground spaces such as tunnels or mines. For example, in certain situations, it may be important to incorporate a time lag between radon concentration measurements and ambient temperature measurements; it may be important to incorporate differences in hydrostatic pressure recorded inside and outside the cave; and it may be important to reintroduce the diffusion term back into the mass balance equation at sites where the distance from any given entrance to the radon monitoring point is small. There are many advantages to being able to produce detailed numerical models that can precisely replicate a wide range of variables. The ultimate aim of this research, however, is to establish a network of monitoring points in 
order to deliver the first real time global radon flux maps. This turns out to be feasible because we can isolate flux in the mass balance equation and compute radon concentration for successive iterations using only routinely available data: radon concentration, inner temperature, and outer temperature. The synchronised analysis of data obtained from across extensive geographical areas would illuminate our understanding of radon migration along crustal discontinuities and our understanding of its subsequent exhalation into the atmosphere.

\section{CONCLUSIONS}

The dynamic nature of radon flux has been investigated in this paper. The first part of the presented numerical modelling procedure focuses on calculating cave air flow velocity while the second part isolates flux in a mass balance equation to simulate real time dependence among the variables. With this information it was then possible to deliver an expression for computing cave radon concentration for successive iterations. Input data for the model were recorded at Driny Cave in the geodynamically active Little Carpathians Mountains of western Slovakia. Here the cave passages have developed along faults striking broadly NE-SW and NW-SE. Independent experimental observations of fault slip were provided by three permanently installed mechanical extensometers. Our numerical modelling has revealed four important flux anomalies while extensometric measurements demonstrate that each of these was preceded by conspicuous fault slip anomalies. The mathematical procedure outlined in this paper will help to improve our understanding of radon migration along crustal discontinuities and its subsequent exhalation into the atmosphere at the site specific scale. Furthermore, as it is possible to supply the model with continuous data, future research will focus on establishing a series of underground monitoring sites with the aim of generating the first real time global radon flux maps.

\section{ACKNOWLEDGEMENTS}

The authors would like to thank Peter Zvonár, Sara Argerich-Bergada, Amanda KeenZebert, Lenka Thinová, and Petr Otáhal as well as the reviewers whose constructive comments have helped to improve the clarity of the manuscript. This study was conducted with support from the long term conceptual development research organisation RVO: 67985891. It is published in the framework of CzechGeo-EPOS 
"Distributed system of permanent observatory measurements and temporary monitoring of geophysical fields in the Czech Republic" (MŠMT Project: LM2010008).

\section{REFERENCES}

Appleton, J.D., 2013. Radon in Air and Water, in: Selinus, O. (Ed.), Essentials of Medical Geology. Springer, Dordrecht, pp. 239-277.

Åkerblom, G., Mellander, H., 1997. Geology and Radon, in: Durrani, S.A., Ilić, R. (Eds.), Radon Measurements by Etched Track Detectors. World Scientific, River Edge, pp. 21-49.

Badino, G., 2012. Underground meteorology - "What's the weather underground?". Acta Carsologica 39, 427-448. doi: 10.3986/ac.v39i3.74.

Bella, P., 2006. A contribution to the morphology and genesis of Driny Cave. Aragonit 11, 4-9.

Bezek, M., Gregorič, A., Kávási, N., Vaupotič, J., 2012. Diurnal and seasonal variations of concentration and size distribution of nano aerosols (10-1100 nm) enclosing radon decay products in the Postojna Cave, Slovenia. Radiat. Prot. Dosim. 152, 174-178. doi: 10.1093/rpd/ncs218.

Briestenský, M., Rowberry, M.D., Stemberk, J., Stefanov, P., Vozár, J., Šebela, S., Petro, L., Bella, P., Gaal, L., 2015. Evidence of a plate-wide tectonic pressure pulse provided by extensometric monitoring in the Balkan Mountains (Bulgaria). Geol. Carpath. 66, 427-438. doi: 10.1515/geoca-2015-0035.

Briestenský, M., Stemberk, J., Michalík, J., Bella, P., Rowberry, M.D., 2011a. The use of a karstic cave system in a study of active tectonics: fault movements recorded at Driny Cave, Malé Karpaty Mts (Slovakia). J. Cave Karst Stud. 73, 114-123. doi: 10.4311/jcks2010es0166.

Briestenský, M., Thinová, L., Stemberk, J., Rowberry, M.D., 2011b. The use of caves as observatories for recent geodynamic activity and radon gas concentrations in the Western Carpathians and Bohemian Massif. Radiat. Prot. Dosim. 145, 166-172. doi: $10.1093 / \mathrm{rpd} / \mathrm{ncr} 080$.

Briestenský, M., Thinová, L., Praksová, R., Stemberk, J., Rowberry, M.D., Knejflová, Z., 2014. Radon, carbon dioxide, and fault displacements in central Europe related to the Tōhoku Earthquake. Radiat. Prot. Dosim. 160, 78-82. doi: $10.1093 / \mathrm{rpd} / \mathrm{ncu} 090$. 
Cunningham, K.I., Larock, E.J., 1991. Recognition of microclimate zones through radon mapping, Lechuguilla Cave, Carlsbad Caverns National Park, New Mexico. Health Phys. 61, 493-500.

Droppa, A., 1951. Smolenice Karst in the Little Carpathians. Zemepisný Sb. 3, 7-52. Fojtíková, L., Vavryčuk, V., Cipciar, A., Madarás, J., 2010. Focal mechanisms of microearthquakes in the Dobrá Voda seismoactive area in the Malé Karpaty Mts. (Little Carpathians), Slovakia. Tectonophysics 492, 213-229. doi: 10.1016/j.tecto.2010.06.007.

Gregorič, A., Vaupotič, J., Šebela, S., 2014. The role of cave ventilation in governing cave air temperature and radon levels (Postojna Cave, Slovenia). Int. J. Climatol. 34, 1488-1500. doi: 10.1002/joc.3778.

Gregorič, A., Zidanšek, A., Vaupotič, J., 2011. Dependence of radon levels in Postojna Cave on outside air temperature. Nat. Hazards Earth Syst. Sci. 11, 1523-1528. doi: doi:10.5194/nhess-11-1523-2011.

Hakl, J., Hunyadi, I., Csige, I., Géczy, G., Lénárt, L., Várhegyi, A., 1997. Radon transport phenomena studied in karst caves - international experiences on radon levels and exposures. Radiat. Meas. 28, 675-684. doi: 10.1016/S1350-4487(97)00163-7.

Hwa Oh, Y., Kim, G., 2015. A radon-thoron isotope pair as a reliable earthquake precursor. Sci. Rep. 5, 13084. doi: 10.1038/srep13084.

Ielsch, G., Cushing, M.E., Combes, P., Cuney, M., 2010. Mapping of the geogenic radon potential in France to improve radon risk management: methodology and first application to region Bourgogne. J. Environ. Radioact. 101, 813-820. doi: 10.1016/j.jenvrad.2010.04.006.

Igarashi, G., Saeki, S., Takahata, N., Sumikawa, K., Tasaka, S., Sasaki, Y., Takahashi, M., Sano, Y., 1995. Ground-water radon anomaly before the Kobe Earthquake in Japan. Science 269, 60-61. doi: 10.1126/science.269.5220.60.

Košt'ák, B., 1991. Combined Indicator Using Moiré Technique, in: Sorum, G. (Ed.), Field Measurements in Geomechanics. Balkema, Rotterdam, pp. 53-60.

Košt'ák, B., Mrlina, J., Stemberk, J., Chán, B., 2011. Tectonic movements monitored in the Bohemian Massif. J. Geodyn. 52, 34-44. doi: 10.1016/j.jog.2010.11.007.

Kowalczk, A.J., Froelich, P.N., 2010. Cave air ventilation and $\mathrm{CO}_{2}$ outgassing by radon222 modeling: how fast do caves breathe? Earth Planet. Sci. Lett. 289, 209-219. doi: 10.1016/j.epsl.2009.11.010. 
Kováč, M., Bielik, M., Hók, J., Kronome, B., Labák, P., Moczo, P., Plašienka, D., Šefara, J., Šujan, M., 2002. Seismic activity and neotectonic evolution of the Western Carpathians (Slovakia). EGU Stephen Mueller Spec. Publ. Ser. 3, 167-184.

Lenhardt, W.A., Švancara, J., Melichar, P., Pazdírková, J., Havíř, J., Sýkorová, Z., 2007.

Seismic activity of the Alpine-Carpathian-Bohemian Massif region with regard to geological and potential field data. Geol. Carpath. 58, 397-412.

Marko, F., Fodor, L., Kováč, M., 1991. Miocene strike-slip faulting and block rotation in Brezovské Karpaty Mts. Miner. Slovaca 23, 189-200.

Marti, X., Rowberry, M.D., Blahůt, J., 2013. A MATLAB® code for counting the moiré interference fringes recorded by the optical-mechanical crack gauge TM-71. Comput. Geosci. 52, 164-167. doi: 10.1016/j.cageo.2012.09.029.

Michalík, J., Reháková, D., Marko, F., 1992. Stratigraphy and tectonics of the Lower Cretaceous limestone sequence in the profile of Driny Cave (Vysoká Unit, Malé Karpaty Mts). Miner. Slovaca 24, 235-243.

Neri, M., Giammanco, S., Ferrera, E., Patanè, G., Zanon, V., 2011. Spatial distribution of soil radon as a tool to recognize active faulting on an active volcano: the example of Mt. Etna (Italy). J. Environ. Radioact. 102, 863-870. doi: 10.1016/j.jenvrad.2011.05.002.

Perrier, F., Richon, P., Crouzeix, C., Morat, P., Le Mouël, J.-L., 2004. Radon-222 signatures of natural ventilation regimes in an underground quarry. J. Environ. Radioact. 71, 17-32. doi: 10.1016/S0265-931X(03)00117-6.

Plašienka, D., Grecula, P., Putiš, M., Kováč, M., Hovorka, D., 1997. Evolution and Structure of the Western Carpathians: an overview, in: Grecula, P., Hovorka, D., Putiš, M. (Eds.), Geological Evolution of the Western Carpathians. Mineralia Slovaca Monograph, Bratislava, pp. 1-24.

Przylibski, T.A., 1999. Radon concentration changes in the air of two caves in Poland. J. Environ. Radioact. 45, 81-94. doi: 10.1016/S0265-931X(98)00081-2.

Stannard, J.N., 1988. Radioactivity and Health, Springfield, Pacific Northwest Laboratory.

Stemberk, J., Košt’ák, B., Cacoń, S., 2010. A tectonic pressure pulse and increased geodynamic activity recorded from the long-term monitoring of faults in Europe. Tectonophysics 487, 1-12. doi: 10.1016/j.tecto.2010.03.001. 
Swakoń, J., Kozak, K., Paszkowski, M., Gradziński, R., Łoskiewicz, J., Mazur, J., Janik, M., Bogacz, J., Horwacik, T., Olko, P., 2005. Radon concentration in soil gas around local disjunctive tectonic zones in the Krakow area. J. Environ. Radioact. 78, 137149. doi: 10.1016/j.jenvrad.2004.04.004.

Štelcl, J., Zimák, J., Zelinka, J., 2002. Rock mass radioactivity in Driny Cave. Aragonit 7, 25-27.

Tanahara, A., Taira, H., Takemura, M., 1997. Radon distribution and the ventilation of a limestone cave on Okinawa. Geochem. J. 31, 49-56.

Wilkening, M.H., 1990. Radon in the Environment, Elsevier, Amsterdam.

Wilkening, M.H., Watkins, D.E., 1976. Air exchange and 222Rn concentrations in Carlsbad Caverns. Health Phys. 31, 139-145.

Zsíros, T., 2005. Seismicity of the Western-Carpathians. Acta Geod. Geophys. Hung. 40, 455-467. doi: 10.1556/AGeod.40.2005.3-4.15. 


\section{FIGURE CAPTIONS}

Figure 1 The location of Driny Cave in the Little Carpathians Mountains of western Slovakia. This range trends SW-NE along the southeastern margin of the Bohemian Massif and forms part of the Alpine-Carpathian Orogenic Belt. The cave passages have developed along splays of the NE-SW striking Smolenice Fault, which hereabouts marks the contact between the Little Carpathians and the Pannonian Basin, and a series of transverse faults striking NW-SE. Detailed information about the cave and its layout is presented in Michalík et al. (1992) and Bella (2006).

Figure 2 (a) A schematic representation of a cave with an upper entrance and a lower entrance modelled with a height, $H$, a temperature, $T_{i}$, a radon concentration, $C$, the latter provided by spontaneous flux, $\phi$. The outer temperature, $T_{o}$, and atmospheric pressure, $P_{a t m}$, are also labelled while the arrows denote air flow at velocities $V$. (b) Plot of the modelled flow velocities for air passing through either the upper entrance, if $T_{i}>T_{o}$, or the lower entrance, if $T_{o}>T_{i}$. (c) Profile extracted from the modelled air flow velocities which emphasises, first, that air flow ceases when there is no temperature gradient and, second, that the air flow velocity is not a linear function of the temperature gradient.

Figure 3 Flow diagram summarising the numerical modelling procedure needed to isolate flux in the mass balance equation and to compute the radon concentration for successive time instants. The dynamic variables in the model are represented by the outer temperature, the inner temperature, and the radon concentration while the static variables are represented by the radioactive decay constant and a range of parameters related to geometry of the cavity.

Figure 4 An illustrative numerical simulation demonstrating the relevance of Equation 6. (a) A hypothetical ventilation scenario over an arbitrary period. The first half of this period is characterised by increase and decrease in the air flow velocity while the second half is characterised by a complete absence 
of ventilation. (b) A hypothetical flux scenario over the same arbitrary period during which constant flux is interrupted by four spontaneous anomalies. (c) The iterative estimations of radon concentration over the same arbitrary period as calculated using Equation 6.

Figure 5 (a-c) Time series of inner temperature, $T_{i}$, outer temperature, $T_{o}$, and radon concentration, $c$, recorded at Driny Cave for the period January 2010 to August 2011. (d) Plot mapping measurements of radon concentration, $c$, against outer temperature, $T_{o}$, in which the vertical line on the left denotes the freezing point of water and the vertical line on the right denotes no temperature gradient. (e) Plot mapping measurements of radon concentration, $c$, against the intermediate parameter, $T^{*}$, in which the red dashed line emphasises the strong relationship between the measured radon concentration and the temperature gradient. The colour scale represents the number of times an event reoccurs on the corresponding ordinate and abscissa pairing.

Figure 6 (a) Plot mapping radon concentration for successive time instants against flux modelled as a function of the input data recorded at Driny Cave from January 2010 to August 2011. (b) Flux through time modelled as a function of the input data recorded at Driny Cave from January 2010 to August 2011. This plot shows four significant anomalies in January 2010, October 2010, November 2010, and March 2011.

Figure 7 (a) Measured radon concentration, indicated by red dots, compared to radon concentration predictions made with a thirty minute time horizon using Eq. 6, indicated by a blue line. (b) Plot mapping measured radon concentration against radon concentration predictions made with a thirty minute time horizon. (c) The difference between the radon concentration predictions made with a thirty minute time horizon and the a posteriori measured radon concentration. (d) Measured radon concentration, indicated by red dots, compared to radon concentration predictions made with an eight hour time horizon using Eq. 6, indicated by a blue line. (e) Plot mapping measured 
radon concentration against radon concentration predictions made with an eight hour time horizon. (f) The difference between the radon concentration predictions made with an eight hour time horizon and the a posteriori measured radon concentration. (g) Measured radon concentration, indicated by red dots, compared to radon concentration predictions made with a twenty four hour time horizon using Eq. 6, indicated by a blue line. (h) Plot mapping measured radon concentration against radon concentration predictions made with a twenty four time horizon. (i) The difference between the radon concentration predictions made with a twenty four time horizon and the a posteriori measured radon concentration.

Figure 8 Flux modelled through time as a function of the input data in order to interrogate the extent to which our model is sensitive to the parametric inputs. (a) The proportion of the ceiling or entrance which acts an aperture for air flow equates to $0.1 \%$. (b) The proportion of the ceiling or entrance which acts an aperture for air flow equates to $1 \%$. (c) The proportion of the ceiling or entrance which acts an aperture for air flow equates to $10 \%$. In all three cases the cave height is fixed to $40 \mathrm{~m}$ and the cave length is fixed to 100 m.

Figure 9 Time series of direct experimental observations of fault slip recorded across three faults in Driny Cave. The red lines indicate strike slip displacement; the blue lines indicate dip slip displacement; and the grey areas denote periods of three weeks either side of the modelled flux anomalies. (a) The data recorded at monitoring point Driny 1 show a significant dip slip displacement before the flux anomaly in January 2010. (b) The data recorded at monitoring point Driny 2 show a significant strike slip displacement before the flux anomaly in January 2010. (c) The data recorded at monitoring point Driny 3 show significant strike slip displacements before the flux anomalies in October 2010, November 2010, and March 2011. The radon progeny monitor was located in the immediate vicinity of monitoring points Driny 2 and Driny 3. More detailed information about this research is presented in Briestenský et al. (2011a,b). 


\section{TABLES}

Table 1 A summary of the fault slip trends recorded at the three monitoring points in Driny Cave over a nine year period between January 2006 and January 2015.

\begin{tabular}{cccccccc}
\hline \hline $\begin{array}{c}\text { Monitoring } \\
\text { point }\end{array}$ & $\begin{array}{c}\text { Monitored } \\
\text { fault }\end{array}$ & $\begin{array}{c}\text { Total } \\
\text { strike slip } \\
(\mathrm{mm})\end{array}$ & $\begin{array}{c}\text { Annual } \\
\text { slip rate } \\
\left(\mathrm{mm} \mathrm{yr}^{-1}\right)\end{array}$ & $\begin{array}{c}\text { Sense } \\
\text { of } \\
\text { movement }\end{array}$ & $\begin{array}{c}\text { Total } \\
\text { dip slip } \\
(\mathrm{mm})\end{array}$ & $\begin{array}{c}\text { Annual } \\
\text { slip rate } \\
\left(\mathrm{mm} \mathrm{yr}^{-1}\right)\end{array}$ & $\begin{array}{c}\text { Sense } \\
\text { of } \\
\text { movement }\end{array}$ \\
\hline Driny 1 & $\begin{array}{c}\text { Smolenice Fault } \\
\text { (splay) }\end{array}$ & 0.302 & 0.034 & Sinistral & 0.422 & 0.047 & $\begin{array}{c}\text { NW block } \\
\text { uplift }\end{array}$ \\
Driny 2 & $\begin{array}{c}\text { Smolenice Fault } \\
\text { (splay) }\end{array}$ & 0.176 & 0.019 & Sinistral & 0.11 & 0.012 & $\begin{array}{c}\text { NW block } \\
\text { uplift }\end{array}$ \\
Driny 3 & $\begin{array}{c}\text { Transverse Fault } \\
\text { (unnamed) }\end{array}$ & 0.223 & 0.025 & Dextral & 0.171 & 0.017 & $\begin{array}{c}\text { NE block } \\
\text { uplift }\end{array}$ \\
\hline \hline
\end{tabular}




\section{$\mathrm{N}_{11} 0,0 \circ 6 t \quad \mathrm{~N}_{4} 0,0 \circ 8 t$}

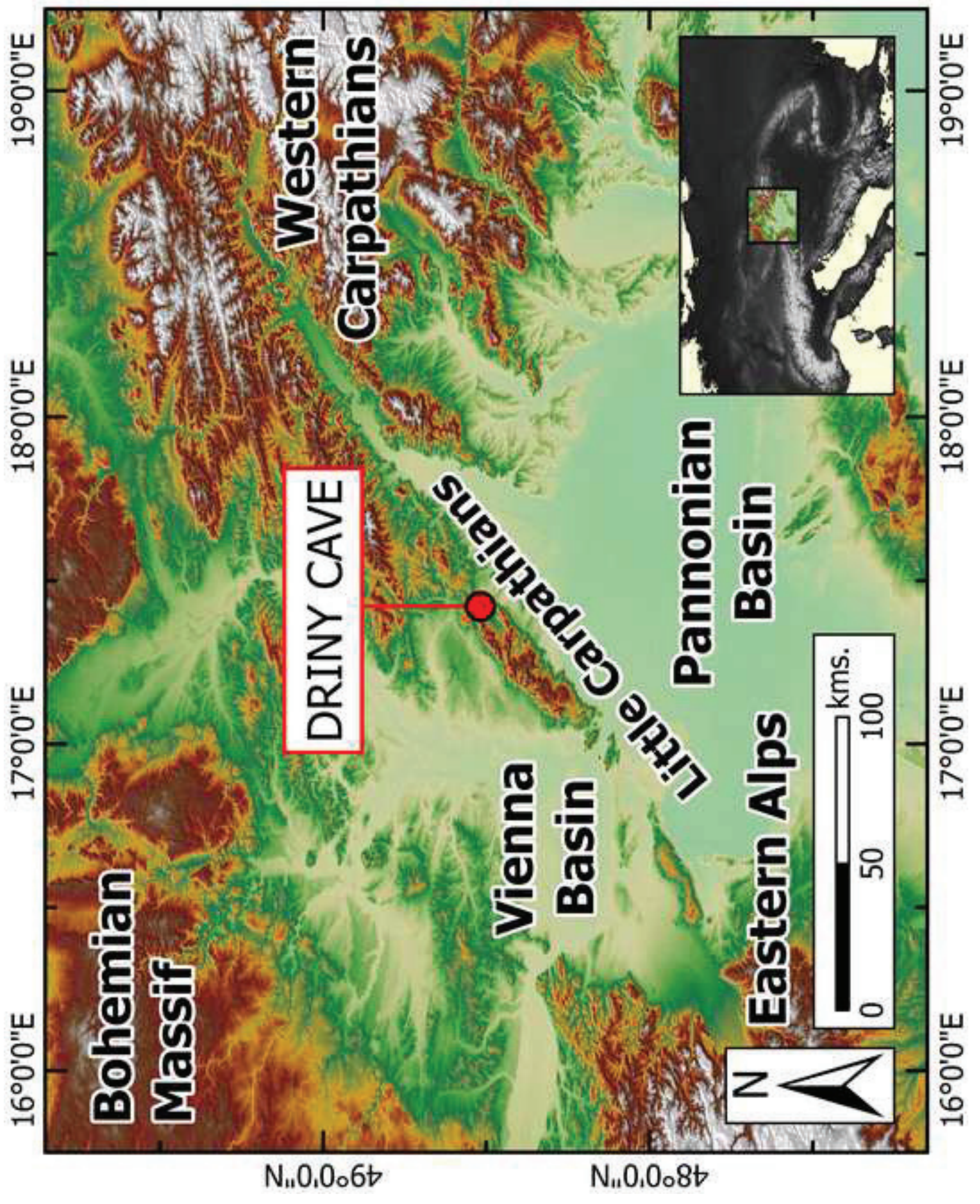


Figure 2

Click here to download high resolution image
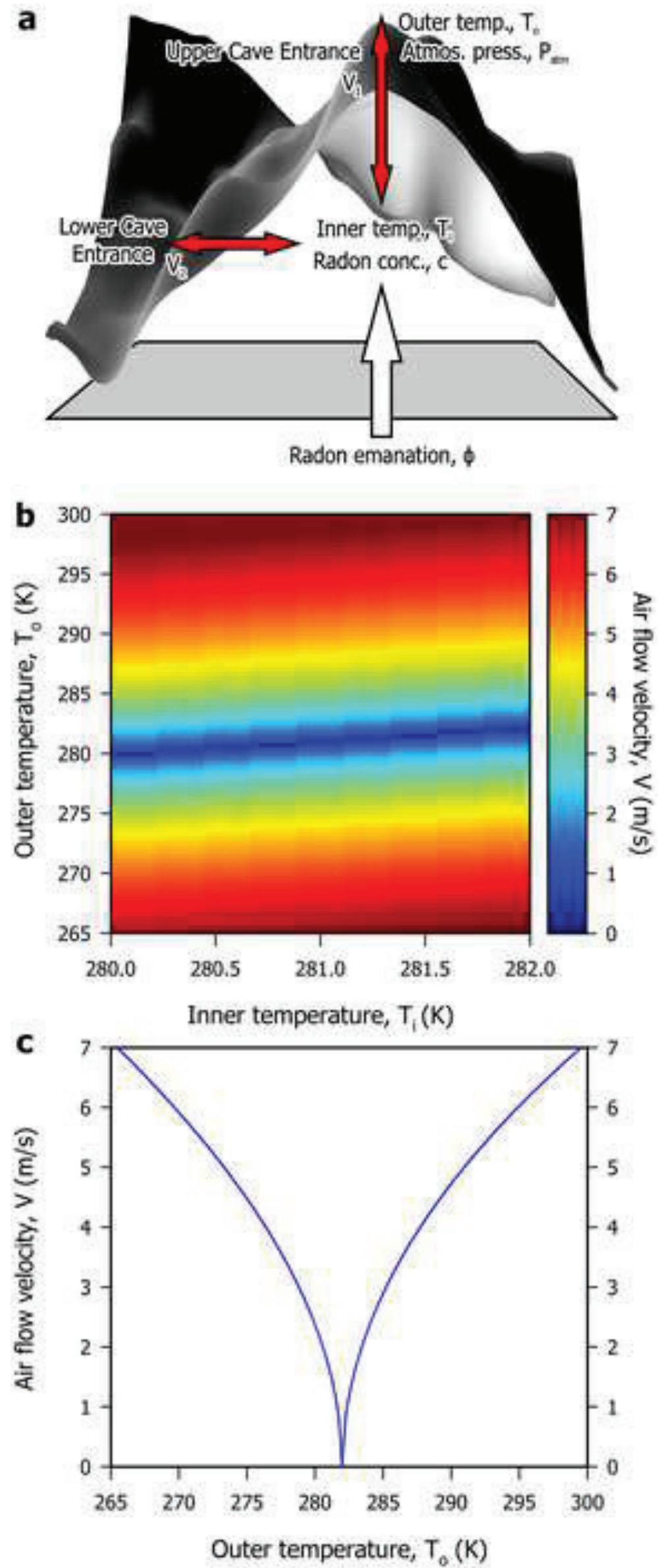
Figure 3

Click here to download high resolution image

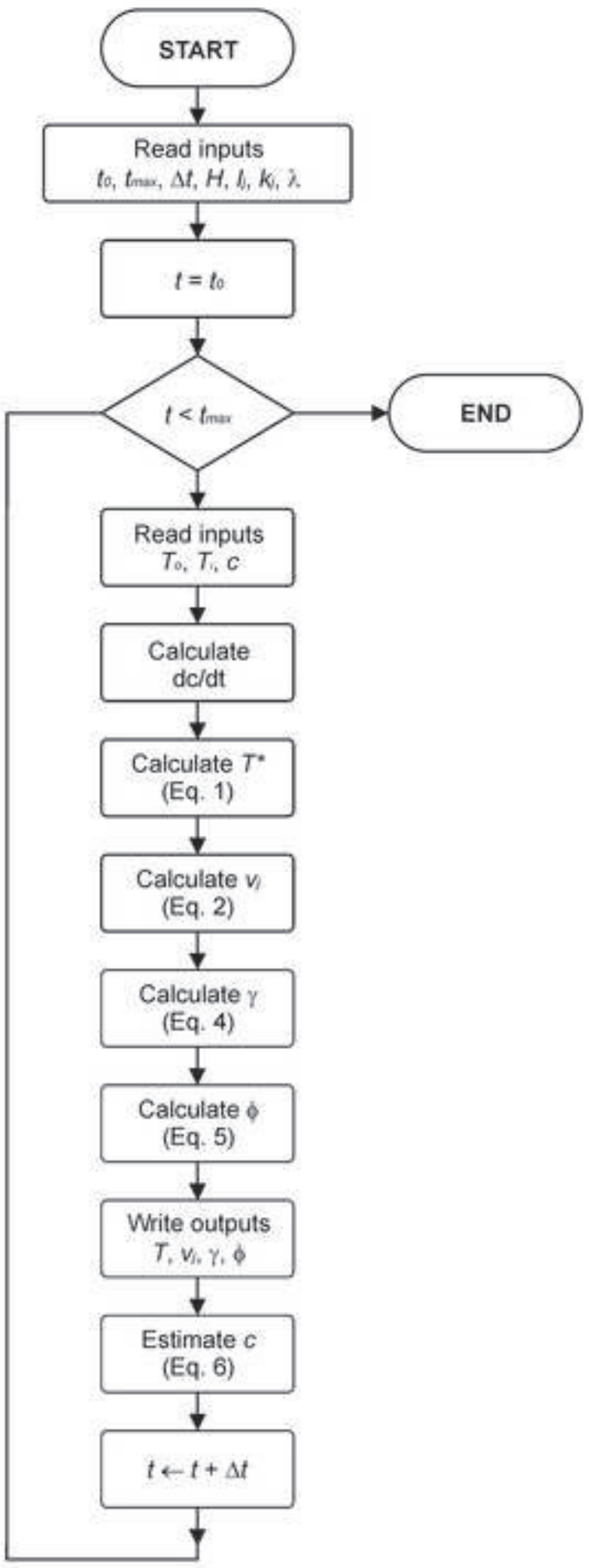



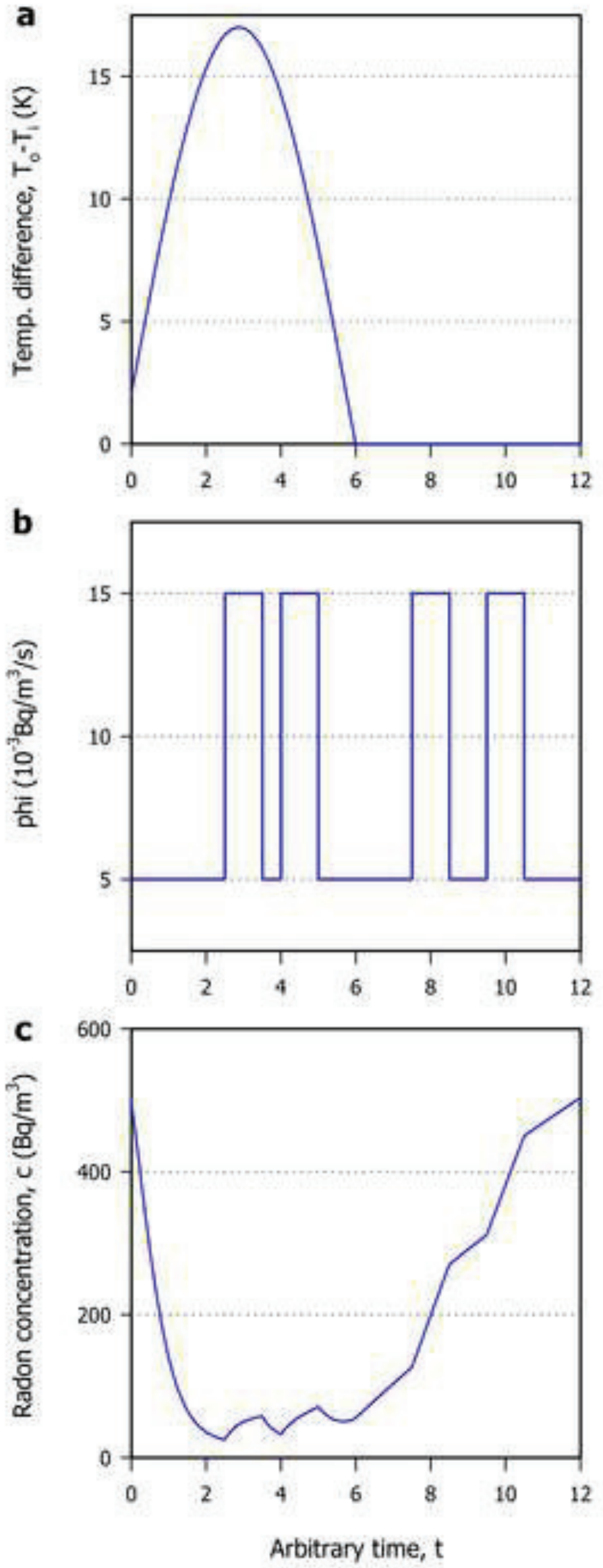

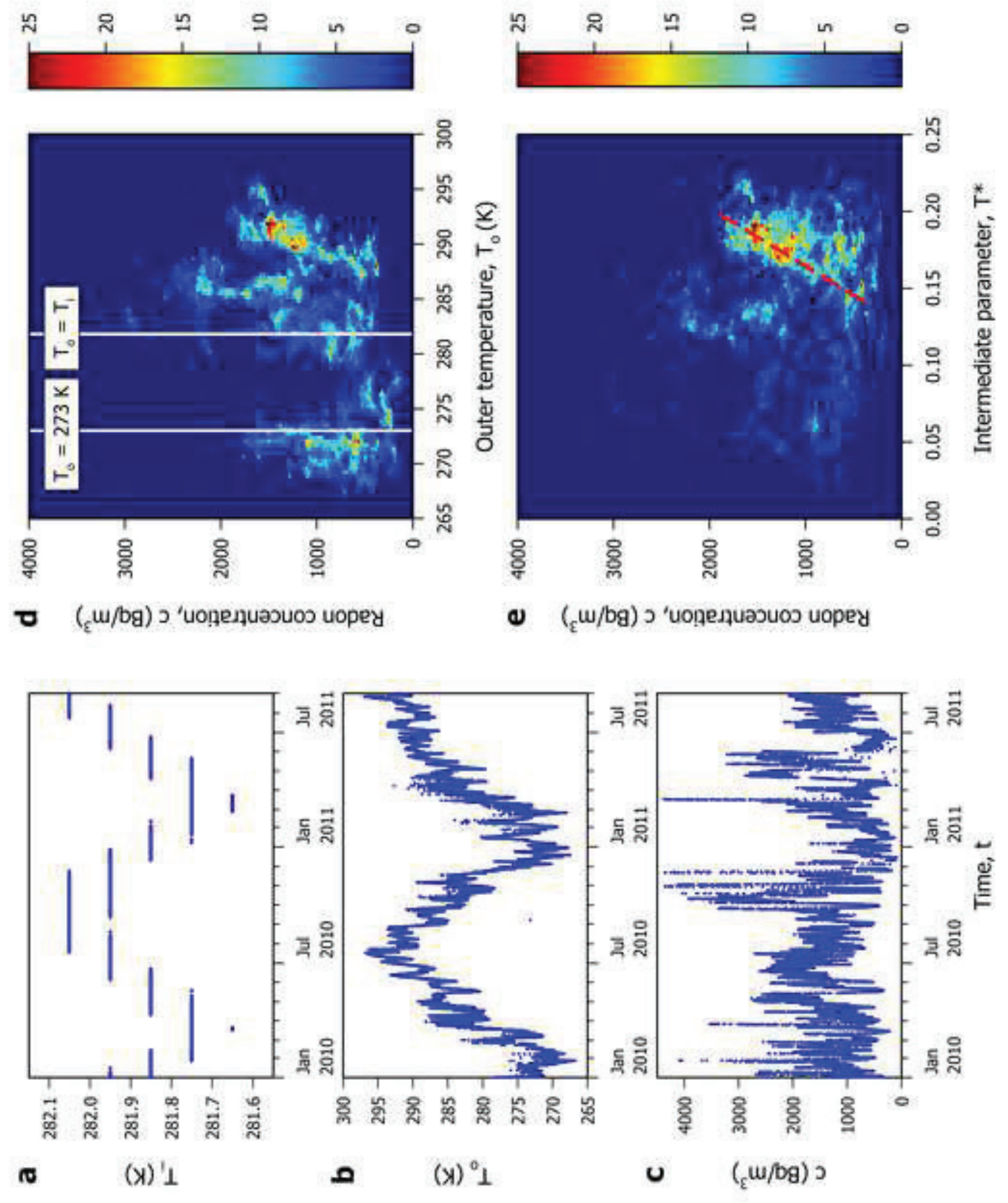


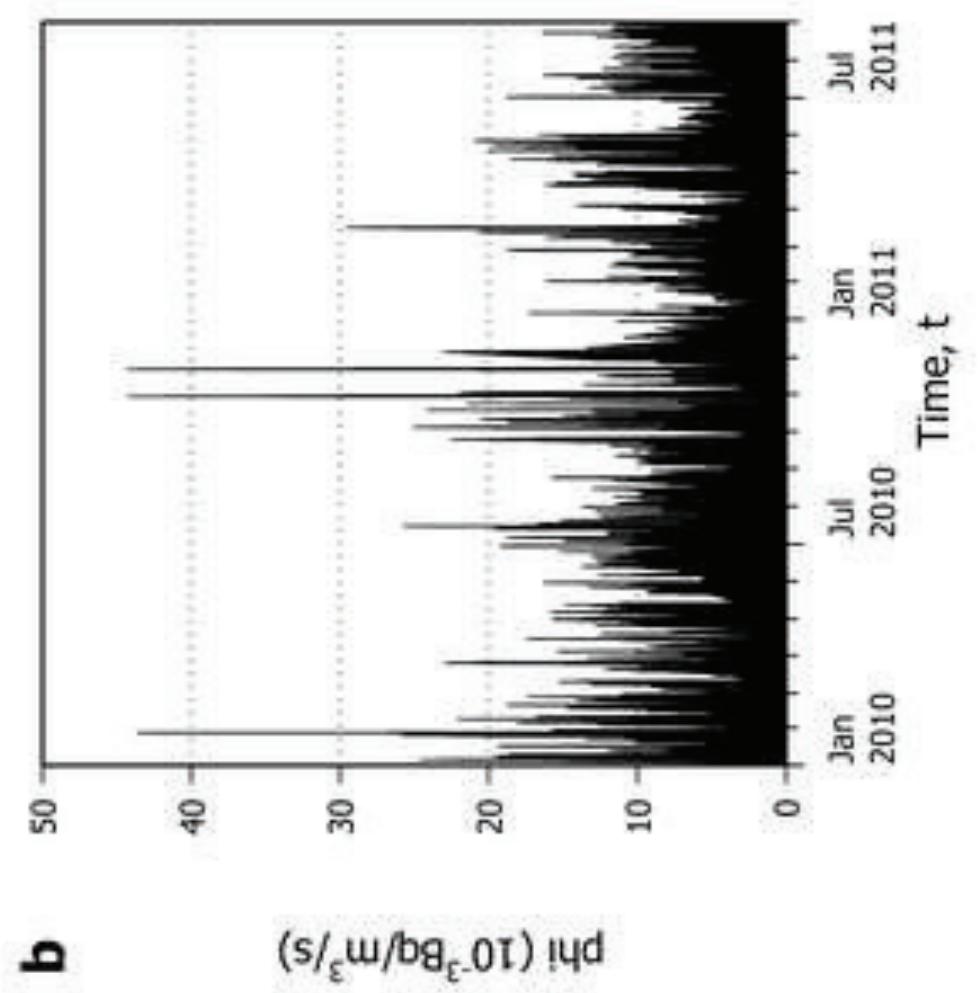

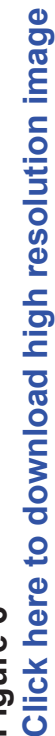

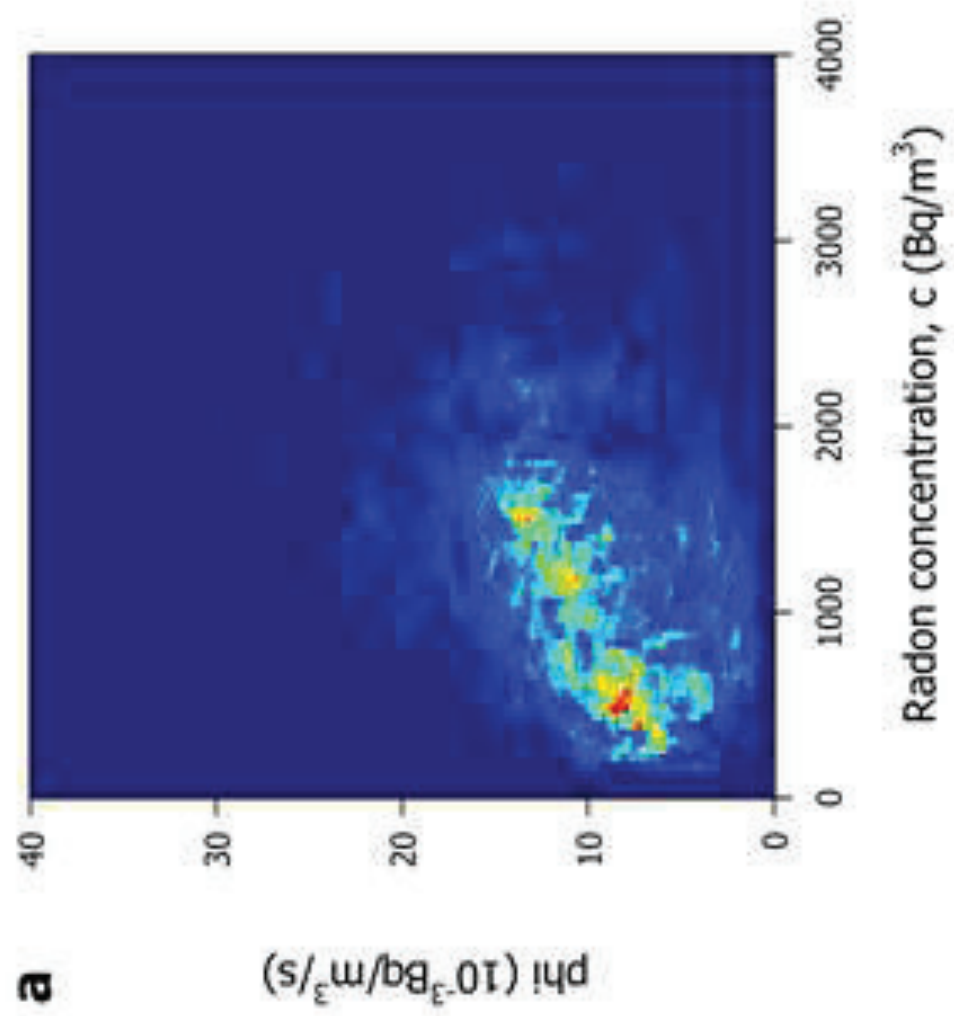


Figure 7

Click here to download high resolution image
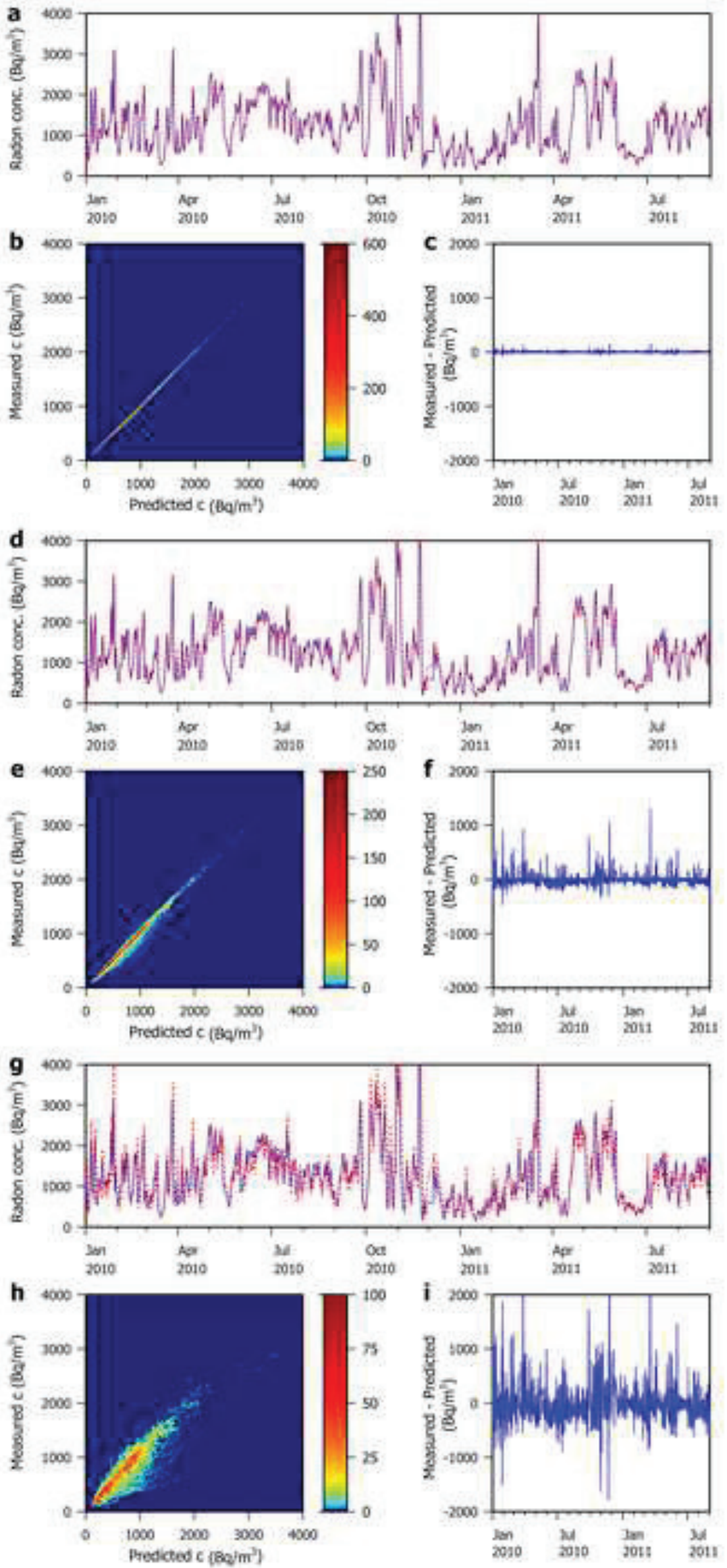

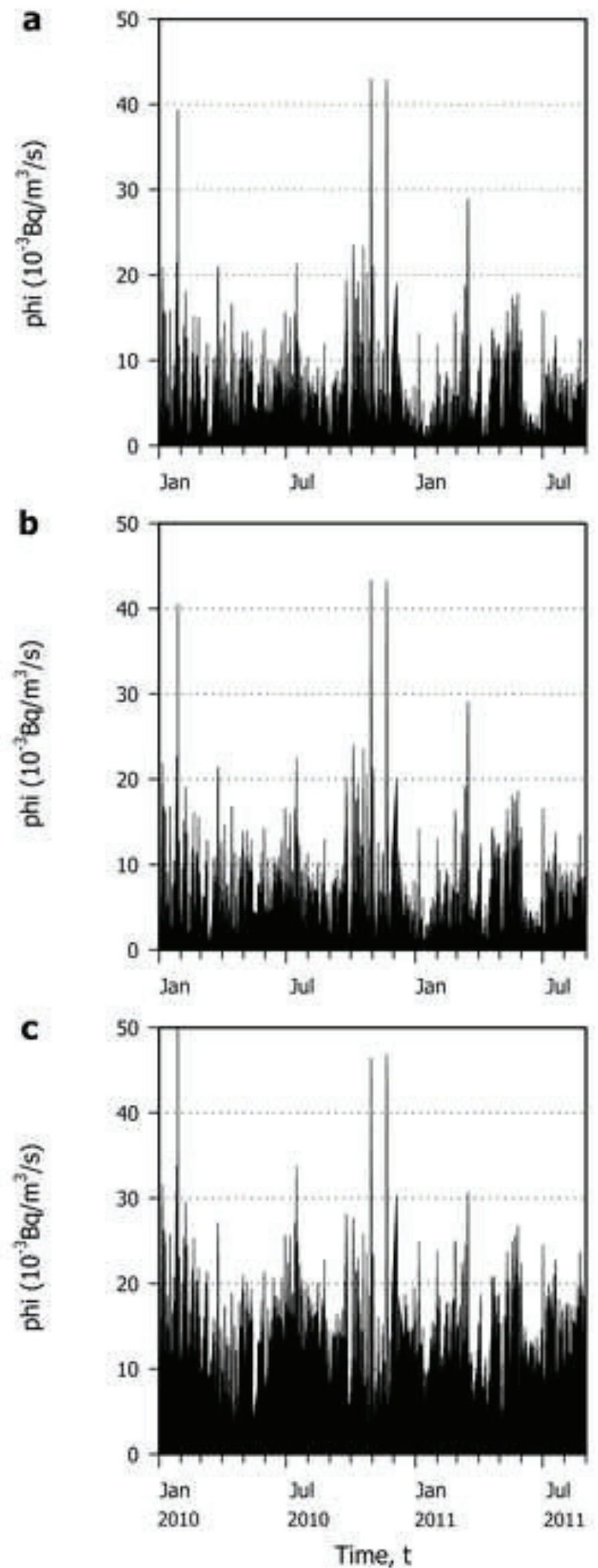
Click here to download high resolution image
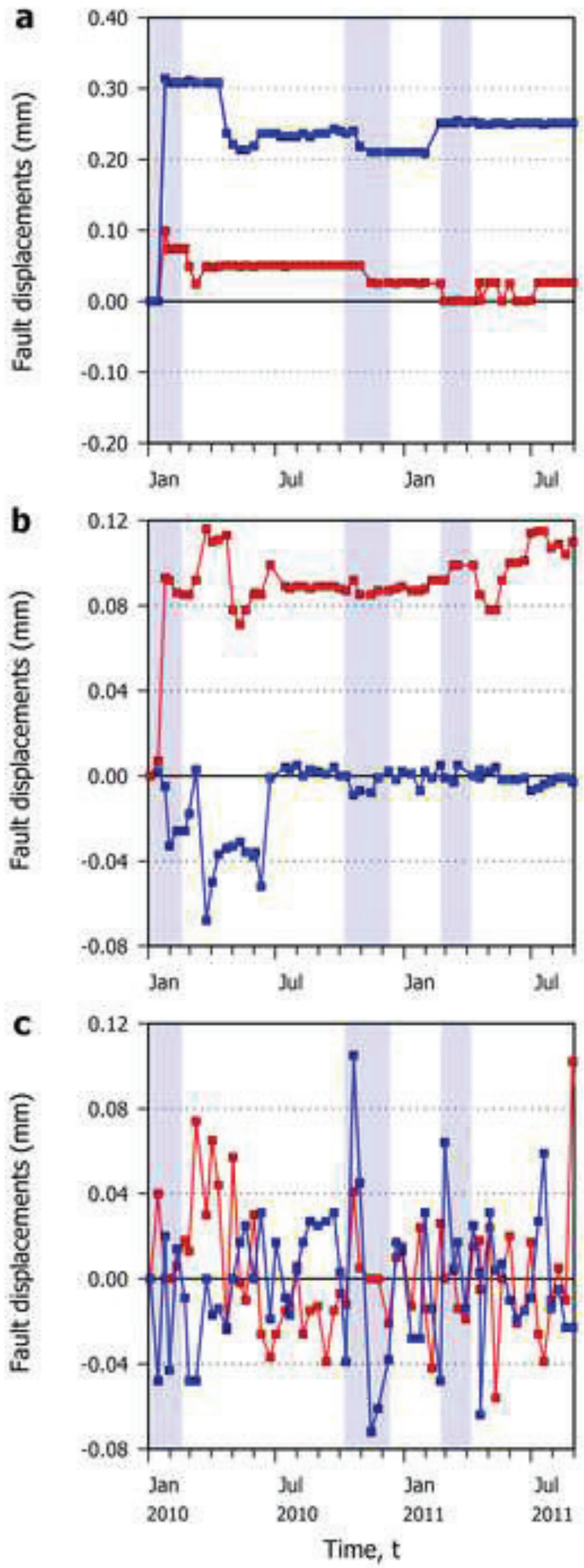